\title{
The role of the Catholic missionaries at Beagle Bay in the removal of Aboriginal children from their families in the Kimberley region from the 1890 s
}

\author{
Christine Choo
}

\section{Preface}

This paper is an edited version of the submission which I made to the Human Rights and Equal Opportunity Commission's (HREOC) Inquiry into the Separation of Aboriginal and Torres Strait Islander Children from their families. In particular it addressed Term of Reference (a): 'Trace the past laws, practices and policies which resulted in the separation of Aboriginal and Torres Strait Islander Children from their families by compulsion, duress or unique influence, and the effects of those laws, practices and policies'. I drew on the research I had undertaken for a doctoral thesis: 'Aboriginal Women on Catholic Missions in the Kimberley, Western Australia, 1900-1950', University of Western Australia.

In addition to this written submission I made a verbal submission at the HREOC hearing in Broome among the descendants of the children who had originally been removed to Beagle Bay Mission. My submission and the contents of my PhD thesis were made available to the Broome Aboriginal community as a contribution to their own preparation the Inquiry. This was a practical way in which the historical research could be used by the Broome community for their own purposes.

\section{Introduction}

From the turn of the century, soon after the establishment of the Aborigines Affairs Department in Western Australia in 1896, a symbiotic relationship developed between the Church and the State, in particular the Catholic missionaries who ran the mission at Beagle Bay and the Aborigines Department. This enabled Church and State to collude in the development of policies and practices which instituted and encouraged the removal of Aboriginal children from their families in Western Australia.

From as early as 1840 John Smithies of the Wesleyan Church had begun his ministry to the Aborigines through works of charity and the creation of a school for Aboriginal children. ${ }^{1}$ The Catholics also engaged in similar works through the initiatives of the Benedictine missionaries Salvado and Torres, who established the mission to 
Aborigines at New Norcia about 128 kilometres north east of Perth in $1846 .{ }^{2}$ However, it was the missionaries at Beagle Bay, in the north-west of the State who persistently pressed government authorities to formalise the State's power to remove "part Aboriginal' children from their Aboriginal families.

The relationship between Church and State benefited both through the development of policies and practices in Aboriginal affairs. In the most minimalist analysis it becomes apparent that by this arrangement the missions gained control of Aborigines, particularly the children, whom they could evangelise and draw into their flock, while the State saved funds in the long run by subsidising the Church missions who took in and cared for Aboriginal children and families. However, the situation was much more complex. The State depended on the Church's support and backing for the moral justification for the removal of Aboriginal children from their families. The Trappist and Pallottine missionaries of Beagle Bay were instrumental in leading the government towards instituting policies for the removal of 'half-caste' and 'part Aboriginal' children from their families and transferring them to missions and other institutions. In Western Australia the Aborigines Act 1905 formalised this arrangement and enabled the Aborigines Department to act with impunity. Throughout the period, from the last decades of the nineteenth century to recent times, both Church and State maintained a tenuous and sometimes antagonistic relationship, each party remaining suspicious of the other yet needing to work together in 'handling' Aboriginal affairs. Contrary to the commonly held view that the Missions acted in response to government policy on the separation of Aboriginal children from their families in Western Australia, the State could not have legislated for the removal of children in the Aborigines Act 1905 and subsequent legislation without the encouragement and compliance of Church agencies.

Ostensibly the children were removed 'for their own good' and to rescue 'half white' children from their 'savage' backgrounds, to give them an education and to prepare them to enter the workforce. However, in reality, Aboriginal children who were removed from their families were stripped of their cultural heritage and their identity as Aborigines belonging to particular families or country. They were given limited formal education and were trained to become the servants of middle class European families, station hands and pastoral workers, labourers engaged in menial work for which employers could not find workers. The missions were dependent on Aboriginal labour to maintain their institutions. The policy of removing Aboriginal children from their families served to provide a powerful means to control a cheap source of labour. For the Church it was a tool of evangelisation.

\section{The Mission at Beagle Bay}

Beagle Bay mission was established in 1890 by French Trappist monks with the encouragement of Bishop Gibney, the Catholic Bishop of Western Australia. For ten years the Trappists laboured to establish their community and mission on the Dampierland Archipelago in this remote region of north-western Western Australia, 120 kilometres north of Broome. The Trappists, a contemplative order, were gentle in their approach to the local Aboriginal tribes. Attempting to attract to their mission as many as possible of

1. McNair and Rumley 1981.

2. Stormon 1977. 
the tribal people of the region, they drew to the attention of the authorities what they considered to be the devastating impact of the pearling industry on the local Aboriginal tribes, and particularly on the women. The increasing concern about the sexual abuse of Aboriginal women by the masters and crews of pearling vessels expressed by the missionaries, concerned individuals and the Aboriginal administration authorities in Perth contributed to the formulation of policy on the control of women in the Aborigines Act $1905 .^{3}$

The missionaries in Beagle Bay and Broome were vocal in their condemnation of the evils of contact between Aboriginal women and Asians, particularly the Malays. As early as 1892 the Trappist monks were aware of the practice whereby women were given to pearlers and their crew for sex in exchange for tobacco, flour and other provisions. They believed that the relationships with Malays, Manilamen, Japanese, Chinese and Indian pearlers were a real source of corruption. Soon after the Trappists arrived in Beagle Bay, Father Alphonse Tachon had asked the women to give up those practices but such a proposition 'caused a general outcry especially among the women'. Father Alphonse had been told that had a native made such a proposition he would have been killed, indicating that the sexual relations between the women and lugger crews had by then been established and were valued by the women of the Beagle Bay area. ${ }^{5}$ The monks found that, in their attempts to evangelise the Beagle Bay people, they could not reach the women and that the women would remain outside the chapel during services. $^{6}$

Wugger crews, too, came to expect that the services of Aboriginal women and girls would be freely available to them and on occasions were prepared to use force to gain access to them. On 31 January 1899 C.J. Daly, an Australian born missionary who had been appointed Native Protector at Beagle Bay, took a statement from Felix Nordintarra, a NjulNjul ${ }^{7}$ leader of the Beagle Bay area converted to Christianity, ${ }^{8}$ who lodged a complaint about a Malay named Ah Mat. Ah Mat had approached Felix's young daughter for sexual intercourse at Alligator Creek and when he was refused, he brought Felix a bottle of gin and a bag of flour as enticement. Again Felix refused to hand over his child but he did so when Ah Mat threatened him with a revolver. ${ }^{9}$ At Alligator Creek, fifteen miles from the mission, there was a pearling station of about forty to fifty luggers, each lugger having six crew comprising chiefly Malays, Manilas and Japanese. Daly noted that it 'would be good if the natives could be protected from fully mixing with these coloured people and likewise the coloured people from mixing with them' ${ }^{10}$

3. Choo 1995 .

4. Manilamen was the common name used to refer to Filipinos.

5. Father Alphonse, Beagle Bay to his Aunt in France, 20 May 1891, collected and translated by Sister Brigida Nailon and included in Brigida Nailon c1987. See also Bishop Gibney, Diary, Sunday Times, 4 December 1927.

6. Abbot Ambrose of Perth to Abbot of Sept Fons, France, 4 August 1892 included in Nailon c1987.

7. NjulNjul was the predominant language group of the Dampierland Peninsula around the Beagle Bay area.

8: Nailon and.Huegel 1990: especially pp. xii, 1.

9. Public Records of Western Australia (SROWA), Aborigines Department, Acc 255 52/99: Beagle Bay Trappist Mission, File Note, Information from Aboriginal Felix Nordintarra taken by C.J. Daly, Native Protector, Beagle Bay, Native Affairs, 31 January 1899. 
The procurement of Felix's daughter by Ah Mat was reported to the police at Broome. Ah Mat was arrested and brought to trial for supplying Aborigines with intoxicating liquor; no mention was made of sexual intercourse with the child. ${ }^{11}$ Supplying Aborigines with liquor was one offence for which it was possible to collect hard evidence which could lead to prosecution while sexual intercourse between Aboriginal women and non-Aboriginal men was more difficult to prove and depended on the admissions of the concerned parties.

Interestingly, the missionaries tended to favour the Manilamen, many of whom were Catholics from the Philippines, above other Asians like Malays, Chinese or Japanese. At the turn of the century, Thomas Puertollano, a Manilaman who had come to Broome as a diver, married a 'half-caste' girl from the mission and settled down at Disaster Bay where he planted a thriving garden the produce of which he sold to passing luggers. ${ }^{12}$ Thomas and his family became staunch supporters of the mission and were themselves supported by the mission. Father Nicholas Emo had taken on a special ministry to the Spanish-speaking Filipinos or Manilamen who worked on the pearling luggers and who visited the ports along the north-west coast, including the centres of Derby and Broome. ${ }^{13} \mathrm{~A}$ number of Manilamen were married to 'mission girls' under Catholic rites of marriage and their families had strong links with the missionaries. Although the Travelling Inspector G.S. Olivey strongly disapproved of the unions he noted that these Church-sanctioned marriages between Asians and Aboriginal women appeared to be happy. ${ }^{14}$

In 1901 the German Pallottines took over Beagle Bay Mission after the departure of the French Trappist order. ${ }^{15}$ The Pallottines were tough and practical men who belonged to a religious order with an apostolic focus, different in temperament and approach from the contemplative Trappists. ${ }^{16}$ The Pallottine priests and brothers included tradesmen and workers who could turn their hand to any form of labour. They were responsible for rebuilding the mission and establishing a clear plan for the evangelisation of the Aborigines of the Dampierland Peninsular. The Pallottines acknowledged that the Catholic Church's mission to the Australian Aborigines was a

10. SROWA, Aborigines, Acc 255 52/99, Letter, C.J. Daly, Native Protector, Beagle Bay to H.C. Prinsep, Perth, 13 March 1899. Daly's suggestion that segregation be introduced was implemented in Sections 36, 39, 40-43 of the Aborigines Act, 1905.

11. Under The Wines Beer and Spirits Sale Act 1880 (44 Vic. No 9) it was an offence to supply or sell spirituous or fermented liquor to Aborigines except in lieu of wages. Amended as The Wines, Beer and Spirits Sale Act 1880 Amendment Act 1886 (50 Vic. No 26)

12. Durack 1969, pp. 78-79, 201-203.

13. Father Nicholas Emo was a Spaniard who had arrived in Beagle Bay in 1895 to join his brother Trappists. He remained in Broome after the Trappists left Beagle Bay.

14. Report on Broome of G. S. Olivey, Travelling Inspector, Annual Report of the Aborigines Department (ARAD) 1901; ARAD 1903.

15. The Pallottines belonged to a Catholic religious order of the Pious Society of Missions (later renamed the Society of the Catholic Apostolate) established by Vincent Pallotti in Italy in 1835. It was a relatively young missionary order when its members arrived in the Kimberley. The German Pallottines came from the mother house at Limberg.

16. The work of apostolic religious orders is essentially focussed on works of the Catholic church 'in the world', for example education, health and welfare activities, while the contemplative religious orders focus on seclusion 'from the world' and prayer in support of the work of the Church in the world. 
particularly difficult one, and attributed this difficulty not to the Aborigines' lack of intelligence but to their nomadic nature and lifestyle and their preference to remain within their own territory. When the Pallottines came to Beagle Bay in 1901, their recommended method of evangelisation was to work with the young members of the community. The Pallottine approach was articulated by Father Walter in his 1928 account of his time at Beagle Bay:

For Aborigines, correct mission method is to let them get used to a settled lifestyle and regular work without using force or restricting their freedom. Only love and a friendly approach can lead to success, not harshness or force. As soon as possible, children can be removed from the adult camp and the nomadic ways of their parents, and be housed in dormitories on mission premises to be educated at school and in trades

...It is not the duty of a Missionary to repress a child's Aboriginal nature and for this reason the children are given as much freedom as possible to follow their customs and practices. From time to time all children are allowed to attend ordinary corrobories (under supervision) and to hold their own corrobories. Outings are utilised to make them sufficiently familiar with bush craft to survive, and one competes with another to catch snakes, lizards, kangaroos and other game, and to study animal trails. ${ }^{17}$

The Pallottine approach to evangelisation-to settle the people and to remove the children-was the one they had adopted at Beagle Bay. Subsequently, through the active pursuance of this policy by the Pallottine missionaries in Western Australia, this approach influenced the development of the State's Aboriginal affairs policy and practice throughout the period 1900-1950.

In 1901, although Beagle Bay Mission was transferred from French Trappists to German Pallottines, little changed for the Aboriginal people who lived there. Luggers continued to anchor in the creeks and bays along the coast of the Dampierland Peninsula and lugger crews continued to have contact with the local people. The Pallottines complained of 'the evil influences of the Asiatics' and asked for a constable to be stationed at Beagle Bay during the lay-up. ${ }^{18}$ By 1903, the police had begun to make regular patrols along the coast to monitor the contact between Asian men and Aboriginal women as a result of continual agitation from the mission and those responsible for other coastal centres like La Grange. On one such patrol near Beagle Bay in January 1904, Police Constable F.B. Cunningham reported the sighting of luggers off shore at various locations accessible to Aboriginal camps where flour, rice, tobacco and other provisions were found when the camps were searched. A couple of mission women had admitted staying on a lugger for two days and a night. Aboriginal groups found camping close to where luggers were moored were ordered to move on. The biggest concern was the fact that the Asians were supplying the Aborigines with liquor, and for this they were arrested, brought before the courts and found guilty. ${ }^{19}$

The missionaries were not alone in their opposition to social and sexual intercourse between. Asians and Aborigines. Their protests were supported by people in

17. Walter 1982, p.124.

18. ARAD 1902, 1903.

19. SROWA, Aborigines, Acc 255 153/04: Broome, Beagle Bay, Cygnet Bay. 
authority in the Kimberley and those who acted as agents for the Chief Protector of Aborigines, for example the police, magistrates, protectors of Aborigines and travelling inspectors. Strong opposition was voiced by F.W. Tuckett, the Postmaster at La Grange Bay, who in June 1900 wrote a confidential letter to H.C. Prinsep, Chief Protector of Aborigines in Perth, expressing his moral outrage at the social and sexual intercourse between Aborigines and Asians. ${ }^{20}$

The missionaries used every opportunity to express their concern about what they considered to be the abuse of Aboriginal women by Asian lugger crew. In June 1904 Father Nicholas Emo, who was aware of the Western Australian government's appointment of Doctor Roth to inquire into 'the Condition of Natives', condemned the practice of procuring Aboriginal women 'for immoral purposes by the Asiatiques' as being more cruel than actual physical ill-treatment. He put forward the mission approach, which favoured the establishment of large reserves, where Aboriginal people could live under Government supervision, and the establishment of small local reserves outside the towns where Aboriginal people worked:

The aboriginals should be compelled to return to these reserves at nightfall, and Asiatics and whites, other than officials, excluded. Steps should also be taken to enforce the placing under proper control and the educating of those unfortunate half-caste and black children who are to be seen in Broome streets, acquiring all the worst vices of Asiatics and blacks and fast qualifying for 'loafers' and a burden on the State. ${ }^{21}$

These and other suggestions put forward by the missionaries were seriously considered and many, like the declaration of 'prohibited areas' and the transfer of 'part-Aboriginal' children to educational institutions, were later implemented.

The missionaries were influential in suggesting policy directions to the government authorities. In July 1904, in response to Father Emo's letter and representation from Father Walter of Beagle Bay, Doctor Blick, the Acting Resident Magistrate of Broome, gave the missionaries provisional approval, subject to ratification by the Chief Protector of Aborigines, 'to collect and train both in elementary and technical education the fatherless half-castes and other aboriginal children who were destitute in Broome'. ${ }^{22}$ This marked the beginning of the policy of actively seeking out and removing Aboriginal children of mixed parentage from their Aboriginal environments in the Kimberley and placing them in missions and other government institutions established to provide for their education and training. The recommendations of the Roth Report supported this approach, which was formalised in the Aborigines Act 1905.

20. SROWA, Aborigines, Acc 255 103/100: F.W. Tuckett, La Grange Bay, List of Aborigines, their Conditions etc. Confidential Letter, F.W. Tuckett, La Grange Bay to H.C. Prinsep, Chief Protector of Aborigines (CPA), Perth, 16 June 1900.

21. SROWA, Aborigines, Acc 255 153/04, Letter, Father Nicholas Emo, Broome to Doctor Blick, Acting Resident Magistrate (RM) Broome, Native Affairs, 30 June 1904. According to Father Emo there were 35 'half-castes' of both sexes and both Christian and non-Christian living in Broome.

22. SROWA, Aborigines, Acc 255 153/04, Letter, Dr G. Blick, Acting RM, Broome to CPA, Perth, 16 July 1904. Both Father Nicholas Emo and Father Walter gave evidence to the Roth Inquiry along these lines. 


\section{Development of government policy on the removal of children}

Government policy on the removal of Aboriginal children with non-Aboriginal parentage to missions and government institutions changed from a laissez faire approach of the nineteenth century to the development of strong legislation in the Aborigines Act 1905 and subsequent even harsher legislation, Aborigines Act Amendment Act 1936 (also referred to as the 'Native Administration Act 1936'). The Aborigines Act 1905 formalised many of the administrative policies and procedures for the stricter control of the lives of Aborigines which the missionaries and government authorities had been suggesting for years. It was the moral outrage of the missionaries, 'upstanding' community members and government instrumentalities in the Kimberley which contributed to the introduction of the harsh legislation.

Prior to the Aborigines Act 1905, although European authorities favoured the removal of children of mixed parentage from their bush environments, they did not have the legal authority to force parents to give up their children. ${ }^{23} \mathrm{~A}$ person deemed to be Aboriginal and subject to the Aborigines Act 1905 was one who was an Aboriginal inhabitant of Australia, a 'half-caste' who was the de jure or de facto spouse of an Aboriginal person, a 'half-caste' who habitually associated with Aborigines or a 'halfcaste' child under the age of sixteen years old (Clause 6). The Chief Protector was made the legal guardian of every Aboriginal and 'half-caste' child under the age of sixteen (Clause 8) and thereby acquired the authority to deal with Aboriginal children in whatever manner he saw fit. One immediate and direct result of the exercise of this authority was the removal and institutionalisation of Aboriginal children with nonAboriginal parentage.

Most of the 'half-caste' children who were transferred to Beagle Bay prior to 1907 had been placed there with the permission of their parents, usually their European fathers, who took some responsibility for the children's care and education. As the European population in Western Australia grew, the increasing numbers of children of mixed racial background became an embarrassment to State government authorities and politicians. As early as 1902 Henry Prinsep, the Chief Protector of Aborigines, had sent a circular letter to all Protectors and Government Residents in Western Australia requesting information about the numbers of 'half-caste children in [their] district who could be induced to enter one of the institutions now existing within the State for their care and education'. ${ }^{24}$ The only recorded response from the Kimberley, from Wyndham, indicated that there were two such children whose mothers would not part with them. It was virtually impossible to make an accurate assessment of the mixed-race population in the Kimberley largely due to the vast distances in the region and non-disclosure.

23. SROWA, Aborigines, Acc 255 122/02: Replies to Circular Letter re. Half-caste Children in WA Who Could be Induced to Enter Missions, Circular Letter 6/146, H. Prinsep, CPA to all Protectors and Government Residents in WA, February 1902. This circular requested information on any halfcaste children in their districts who could be induced to enter one of the existing institutions for their care and education. The replies to this circular from all parts of the state indicated that where such children had been located, almost all the mothers could not be induced to part with their children, and where the parent had agreed, the arrangements for the children's removal were undertaken hastily in case the mother changed her mind.

24. SROWA, Aborigines, Acc 255 122/02, Circular Letter 6/146, Henry Prinsep, CPA to all Protectors and Government Residents in Western Australia, February 1902. 
As a result of this inquiry Prinsep decided to wait for another year or two when he would be able 'to interfere with more legal authority'. ${ }^{25}$

The government's decision to strictly enforce the Aborigines Act 1905 after its introduction resulted in the big influx of the first generation of 'half-caste' children who were brought to Beagle Bay mission from the Kimberley area in 1907. Police and protectors were instructed to collect all children of mixed ancestry for placement in missions and government institutions. Many of these children were accompanied by their mothers who settled in 'the Colony', that is, the Aboriginal community outside the mission compound. The Pallottine brothers were in charge of the boys while the St John of God sisters who had arrived at Beagle Bay in 1906 cared for the girls.

The effect of the implementation of the Aborigines Act 1905 in the Kimberley was a fourfold increase in the number of children received at Beagle Bay Mission as the following tables show. There was a dramatic increase in 1909, when the government authorities, on the instruction of the Chief Protector, mounted a special campaign to pick up all part-Aboriginal children in the Kimberley. Table 1 indicates the dramatic increase in the number of new children who were sent to Beagle Bay Mission between 1895 and 1909. Table 2 shows the number of children cared for by the missionaries at Beagle Bay Mission between 1910 and 1936. The figures in Table 2 are incomplete because the Annual Reports for those years did not provide the information necessary to compile the table.

\section{Beagle Bay Mission's response to government initiatives to remove children}

Following the Aborigines Act 1905 the Beagle Bay missionaries were willing to take as many children as could be transferred to the mission. Among the children and young people who were removed to the mission were those who were considered to be in moral danger. The missionaries wished to rescue the young people, especially the girls, from sexual interference by men. In 1906 Father Walter pressed the Chief Protector of Aborigines, Prinsep, to send the 'neglected native children in the Nor-West' to the mission 'at once' and at the same time requested government assistance for the maintenance of the children on the mission, making an attractive offer to the Chief Protector:

If the Government will assist me for a few years [at 1shilling per day per child] in the maintenance of 30 [of the fifty] of these children, I will gladly take, without question of remuneration, as many more as it will send me from the Nor-West. ... many full blood and half-caste children (your wards, Sir, according to Section 8 of the Aborigines Act) may be found roaming about Broome and other North-Western towns, beginning the worst and most unhappy lives. If the police sent me only the most obvious cases, the number of children on the mission would be about $200 .^{26}$

Prinsep, in considering this offer, recognised its value to the department although he noted that Father Walter probably made the offer with a view to 'increasing the numbers of his religious denomination'. The mission's offer would relieve the State of the burden of the responsibility for the care and education of Aboriginal and part-Aborig-

25. SROWA, Aborigines, Acc 255 122/02, Comment on Note Number 1/285, Henry Prinsep.

26. SROWA, Aborigines, Acc 255 24/06, Letter, Father G. Walter, Superior Beagle Bay Mission to CPA, Perth, 12 October 1906. 
Table 1 Children at Beagle Bay Mission, 1895-1909

\begin{tabular}{lrcccc}
\hline Year & No. & Year & No. & Year & No. \\
1895 & 3 & 1900 & 1 & 1905 & 9 \\
1896 & 2 & 1901 & 1 & 1906 & 7 \\
1897 & 1 & 1902 & 3 & 1907 & 16 \\
1898 & 0 & 1903 & 3 & 1908 & 16 \\
1899 & 2 & 1904 & 12 & 1909 & 36 \\
\hline
\end{tabular}

Total number of children admitted to Beagle Bay mission by $1909=111$ Note that these figures represent the number of children who were admitted to the mission's care.

Source: SROWA, Aborigines and Fisheries, AN 1/3 Acc 652 1436/09: Beagle Bay Mission-Number of Children Receiving Education

inal children while the State would be seen to be doing something for these children by providing a subsidy to the mission for their care. Beagle Bay Mission received a subsidy of $£ 500$ for the year, which was a little less than the amount suggested by Father Walter. $^{27}$

In response to Father Walter's appeal that children be sent to the mission Prinsep instructed the Protectors, Police and Travelling Inspectors to collect Aboriginal and part-Aboriginal children from around the Kimberley and to send them to Beagle Bay Mission. He acknowledged that the parents did not want to part with their children and that they could not be forced 'unless it is proved that the surroundings are likely to bring the children to lead vicious lives'. ${ }^{28}$ The missionaries, delighted with this response, claimed that by then (1907) every child over the age of seven in the mission area was in their care and they hoped that the custom of giving children into the care of the missionaries would be extended to the whole Dampierland Peninsular. As the care of the 'half-caste' children was of particular concern to them, the missionaries hoped to have control of all such children in the Kimberley. ${ }^{29}$

The increased responsibility of the mission in providing education and training for Aboriginal children with mixed race backgrounds called for the presence of female missionaries. Up to this time there had been no female missionaries in the Kimberley. Nine sisters of St John of God arrived from Ireland via Kalgoorlie and Subiaco to Broome and Beagle Bay on 6 June 1906 'to take charge of the native children there'. ${ }^{30}$

27. SROWA, Aborigines, Acc 653 11/15: Grants to Missions, Memo 696/06, H. Prinsep, CPA to Under Secretary Re. Subsidies to Missions, November 1906.

28. ARAD 1907.

29. Report of the Beagle Bay Mission to CPA, ARAD 1907.

30. SROWA, Aborigines, Acc 255 24/06, Letter, Father J. Bischofs, Protector of Aborigines, Beagle Bay Mission to CPA, Perth, 8 May 19107. 
Table 2 Children at Beagle Bay Mission, ${ }^{1} 1909-1936$

\begin{tabular}{lccccc}
\hline Year & No. & Year & No. & Year & No. \\
1920 & 105 & 1920 & $\mathrm{na}^{3}$ & 1930 & 107 \\
1911 & 94 & 1921 & 80 & 1931 & 110 \\
1912 & 131 & 1922 & na & 1932 & 117 \\
1913 & 147 & 1923 & 70 & 1933 & $\mathrm{na}^{3}$ \\
1914 & 143 & 1924 & 72 & 1934 & $\mathrm{na}^{3}$ \\
1915 & $130^{2}$ & 1925 & 80 & 1935 & $\mathrm{na}^{3}$ \\
1916 & $132^{2}$ & 1926 & 87 & 1936 & 124 \\
1917 & $\mathrm{na}^{3}$ & 1927 & 83 & & \\
1918 & $\mathrm{na}^{3}$ & 1928 & 90 & & \\
1919 & $\mathrm{na}^{3}$ & 1929 & 91 & & \\
\hline
\end{tabular}

(1) These figures are taken from the Annual Reports of Beagle Bay mission.

(2) = Children at school

(3) na = Not available: the figures were unavailable in the Annual Reports. The language of the Annual Reports is sometimes ambiguous and it is difficult to determine whether the figures refer to total numbers of children at the mission or to children who were being educated at the Mission. These figures should be taken as an indicator of the trends in the population of children at Beagle Bay. About $20 \%$ were supported by the state, the rest were supported entirely by the mission or with minimal financial assistance from their fathers.

Source: Annual Reports of the Aborigines Department, 1910-1936

The presence of the St John of God sisters at Beagle Bay enabled the mission to expand its intake of Aboriginal children.

The number of children at the mission increased from around 60 in $1907^{31}$ to 94 in 1909 , a situation which prompted the Pallottines to request a capitation grant from the government. ${ }^{32}$ Not only did the Pallottines press the government authorities to send more 'half-caste' children to the mission, but the missionaries also were proud to announce that in 1907 they had responsibility for the care of every child over seven years of age in the Dampierland Peninsular. ${ }^{33}$ They acknowledged that, since the sisters had arrived, the mission had been able to give the Aboriginal children in their charge an education equivalent to that offered to European children in the Catholic primary schools in Perth. ${ }^{34}$

31. ARAD 1907.

32. SROWA, Aborigines and Fisheries Department, Acc 652 1003/09: Beagle Bay Mission-Copy of Report on Mission since 1900.

33. ARAD 1907: 12.

34. ARAD 1907: 12. 


\section{Support from James Isdell, Protector of Aborigines in the Kimberley}

The removal of Aboriginal and 'caste' children from their families had the full support of the Police as well as that of the Travelling Inspector and Protector of Aborigines in the Kimberley, James Isdell, who was convinced that such a move was absolutely necessary for the future welfare of the children. His statement in his annual report for 1909 indicates his attitude towards the Aboriginal mothers:

The half-caste is intellectually above the aborigine, and it is the duty of the State that they be given a chance to lead a better life than their mothers. I would not hesitate for one moment to separate any half-caste from its aboriginal mother, no matter how frantic her momentary grief might be at the time. They soon forget their offspring. ${ }^{35}$

James Isdell, who visited Beagle Bay Mission in 1908, stated in his report on the visit that he was satisfied that the Mission was doing 'a great and good work to these waifs and strays from the native camps' and that they were 'being well taught and equipped with serviceable and useful knowledge for their future life'. He concluded his report by stating that the 'rescuing of waifs and strays from the bad contaminating influence of natives' camps and training them at this Mission is well worthy of deep consideration by the Government and the support of the general public' ${ }^{36}$ Isdell's support for the mission was significant for the mission's credibility with the government authorities in Perth, whom the missionaries regularly approached for funding, and who later adopted the missionaries' plan for the widespread removal of Aboriginal ('half-caste' and 'quarter caste') children from their families for placement at the mission. It was Isdell who persistently urged the Chief Protector of Aboriginal Affairs and his Department to take a more active role in the removal of 'half-caste' children from their Aboriginal families. He did this by bombarding the Chief Protector with submissions, reports and letters on the topic, taking an active part in identifying and locating the 'half-caste' and 'mixed blood' children in the Kimberley and personally making arrangements for their removal. The mission's willingness to care for the children, and the presence of the St John of God sisters, facilitated the pursuance of the policy of removal. In November 1908 Protector James Isdell wrote from GoGo Station in the East Kimberley to the Chief Protector of Aborigines,

I would again draw your attention to the necessity of steps being taken to have removed to the Mission Station Beagle Bay the many half-castes on Fitzroy River amongst them are girls who will assuredly go to the bad within the next twelve months, and we will have a repetition of the Noonkenbah Station cases where a half-caste girl has already two children by white fathers. I consider it a great scandal to allow any of them to remain with the natives. Station managers have asked to have them removed. A few of these girls will simply be prostitutes if allowed to remain another twelve months. A proper outfit and system should be adopted so as to collect them all, as previously recommended by me. ${ }^{37}$

35. ARAD 1909.

36. ARAD 1908: 20. The full text of Isdell's report on the Beagle Bay Mission included in ARAD 1908 (pp 19-22) provides a good description of the Mission from the perspective of an observer who was not a missionary or associated with the missionaries.

37. SROWA, Aborigines and Fisheries, Acc 652 106/09: Half-castes East and West Kimberley, Letter James Isdell, GoGo Station to CPA, Perth, 13 November 1908. 
The Chief Protector of Aborigines responded to this letter by giving Isdell the authority to make all necessary arrangements to remove all 'half-castes' under sixteen years of age to the Mission. ${ }^{38}$

Following instruction from the Chief Protector of Aborigines to collect all the 'half-castes' in the Fitzroy Crossing area, Isdell undertook this sorry task in October 1909. On this trip Isdell reported that he had 'pretty well cleaned the Fitzroy District' of 'half-castes', leaving only nine adults, three babies and two ten year olds who could not be reached because they had gone away into the bush. During the 33-day journey in extremely hot and difficult conditions, when the temperature reached $110^{\circ} \mathrm{F}$ in the shade, Isdell walked on foot while the children of various ages whom he had collected took turns to travel in a mule cart. Two children had to be sent forward to Derby because they became very ill. A number of children attempted to escape into the bush and a couple succeeded in breaking away from the group. When he reached Derby, Isdell delivered 19 children to the police for transfer to the mission, convinced that 'looking after a wild lot of half-caste kids like young kangaroos [was] a strenuous undertaking'. ${ }^{39}$ The children were later sent from Derby to Broome. A small group of youths were sent to Drysdale River mission in the far north of the Kimberley, where Benedictine monks had established a mission in 1907. These young boys assisted the Benedictines in their work on the new mission. ${ }^{40}$

At Beagle Bay life was regulated and institutionalised. All children of school age were cared for in the confines of the dormitory and the mission compound. They were allowed to visit their families in the Colony for a picnic or an outing only once a month, although they could see them across a fence every day. The children were not allowed to speak their own languages or practise their traditions and customs. They were locked in the dormitory at night. Because most of the children who had been transferred to Beagle Bay in these early years had European fathers, the missionaries were determined to educate and train the children in European ways. By providing these 'half-caste' children with training the missionaries intended to 'rescue' them from their 'native ways'.

\section{Role of the St John of God Sisters and the provision of educational opportu- nities for Aboriginal children in the Kimberley}

In June 1906, nine Sisters of St John of God came to Beagle Bay Mission. ${ }^{41}$ The presence of the sisters, whose main responsibility was to care for the Aboriginal children who were being sent to Beagle Bay, made an enormous difference to the activities of the mission. In his letter informing the State Treasurer of their arrival in Beagle Bay the Bishop of Perth, Bishop Gibney pressed for the removal to the mission of 'several hundred halfcaste children in the Kimberley district who [could] be made useful citizens' ${ }^{42}$

38. SROWA, Aborigines and Fisheries, Acc 652 106/09, File Note, C.F. Gale, CPA, 15 January 1909, instructing that wire be sent to James Isdell, Halls Creek, "You have authority to make all necessary arrangements to collect all half-caste girls and boys and transport them to Beagle Bay Mission via Broome by Bullarra".

39. ARAD 1910.

40. SROWA, Aborigines and Fisheries, Acc 652 106/09.

41. ARAD 1907; Mechtilde 1961, pp. 6-7; Durack 1969, chapters 17 and 18; Zucker 1994, chapter 7. 
The arrival of the St John of God sisters at Beagle Bay marked a watershed in the operation of the mission, particularly in the mission's ability to care for women and children. The presence of the sisters, with their feminine and maternal influence, released the Pallottine brothers from household chores and freed them for 'men's work', that is planting, building and cattle work on other parts of the mission. The sisters also had a settling effect on the mission. Reflecting on the sisters' contribution, Father Walter wrote in 1928:

Their active contribution and prayerful lives helped mould the Mission. With maternal care they devoted themselves to the children and nursed the old and the sick. The nuns also took charge of the school which now had 90 boys and girls who often tested their patience. Untamed children, used to the freedom of the bush, took time to settle into Mission routine. ${ }^{43}$

From the time the sisters took over the school at Beagle Bay in 1906 through to the 1950s, the children were given as good an education as the sisters were able to provide. It was equivalent to primary-level education in the State schools. As the aim of the missionaries was to prepare the young people for the workforce, a functional education at primary school level was thought to be sufficient for both girls and boys. This was the standard education available to all children (Aboriginal and non-Aboriginal) in the Kimberley. Parents who wanted their children to further their studies beyond primary school level sent their children to boarding schools in the south. Such an option was practically and financially unavailable to Aboriginal children. The racist social environment in Australia, in which Aborigines were actively discriminated against and treated as uneducable outcasts, meant that Aboriginal children were effectively excluded from education under the State school system. Their education was confined to that provided in missions and government institutions. Beagle Bay mission, therefore, did provide well for the children in their care by giving them the best education they could offer. ${ }^{44}$

The missionaries' plan was to provide education and training to Aboriginal young people who showed promise so that they could then return to their communities to work with their own people. This was clearly a developmental approach to evangelisation which was in line with the Pallottines' original focus in their work in the Kimberley. Bishop Raible had written to Archbishop Prendiville in December 1940:

What $I$ have in mind in particular is social and parochial work in connection with catholic action. The growing half-caste population calls for workers that [they] respect from their own ranks and the sooner we take the necessary steps to secure a thorough training of these workers, the better it is. ${ }^{45}$

It was only in in the late 1940 s and the 50 s that young Aboriginal people who were considered to have the potential for further post primary education were sent to Catholic

42. Roman Catholic Archives of the Archdiocese of Perth (RCAAP) C21 1/4, Bishop of Perth to the Hon. Colonial Treasurer, 22 May 1907.

43. Walter 1982, p. 168.

44. Haebich 1988, pp. 82, 85, 260-61. Later, the Pallottines set up boarding facilities in Rossmoyne for this purpose in 1955. Until the 1970's when the first senior high school was built in the Kimberley, all parents who wanted their children to receive secondary school education had to send them to bording school in Perth or elsewhere. This option was not available to poor families and Aborigines. Bishop O. Raible to Archbishop Prendiville, 5 December 1940 in Nailon c1987. 
institutions in the south-west. The Pallottines established a hostel for Aborigines in Rossmoyne in 1955. Young people whom the missionaries considered had special talent or potential were selected for transfer, their parents' permission was sought and they were sent south to board at Rossmoyne while attending Catholic secondary schools or undertaking apprenticeships.

\section{Impacts of the removal of Kimberley Aboriginal children from their families}

The removal of children from their families had a devastating effect on the Aboriginal communities in the Kimberley, where it was acknowledged that 'half-caste' children included children whose fathers were Asians and men who were other than Aboriginal. The policy concerning the removal of children was used to 'rescue' Aboriginal children with mixed-race backgrounds from their 'primitive' bush environments and immorality and to train them as a cheap labour force for Europeans. The girls were trained as house servants and the boys as tradesmen and station hands. ${ }^{46}$

One of the most significant effects of the transfer of children to the dormitories which occurred between 1900 and the 1950s was the loss of contact with the older members of their families and communities, and consequently the erosion of their knowledge of traditional life. Generations of Aboriginal women who lived on Beagle Bay mission have spoken about their sense of loss of culture, and their attempts as children to maintain contact with the older people in order to obtain information about the old ways, which the missionaries frustrated. As children they were not allowed to talk about their parents or enquire about them; they were forbidden from speaking their own languages, among themselves or with the older people in the Colony; the parents who lived in the Colony were not allowed to visit or make unregulated contact with the children. However, the old people ('grannies'), parents and the boys and girls did make contact across the mission fence. They also had the opportunity to teach and learn a little of their indigenous languages and about their bush food when they went on outings and picnics with their relations. The women elders who had knowledge of the traditional ways would take these opportunities to teach the young girls about their culture. The girls would volunteer to run errands to the camp in order to see the elders in their bough sheds. The 'grannies' would save wild honey, cooked kangaroo or damper for the children. ${ }^{47}$

Despite the prohibitions imposed on the maintenance of their indigenous culture, both the elders and younger people who lived on the mission attempted to maintain some remnants of their values and cultural practices. Women were active in this role. There were elders on the mission, women and men, who did hold knowledge of sacred songs, dances, designs and sacred objects and who continued to practice their own traditions including initiation ceremonies for selected men and boys. Although the children learned some of the dances and songs, their participation remained at the level of the uninitiated. ${ }^{48}$ They were aware, however, of some of the taboos related to the traditional practices and were told not to approach certain locations in the bush which they later realised had been identified as sacred ground or places where sacred objects had

46. See Haebich 1988 for the impact of the legislation in the South West of Western Australia.

47.

G. Ah Mat, interviewed by the author in Darwin, 26 June 1992.

48. B. Hancock, interviewed by the author, Darwin, 26 June 1992. 
been kept. ${ }^{49}$ As they grew to adulthood, few mission children were initiated into the deeper aspects of their cultural practice. The children's mission upbringing instead initiated them into the mysteries of the Catholic faith and the European way of life. While a great deal of the local culture and languages have been lost through the mission policy of active prohibition, in the 1950s missionaries who were anthropologists themselves studied the languages and began to combine Aboriginal and European expressions of Christianity in Catholic ritual. ${ }^{50}$

\section{Concluding remarks}

Between 1901 and World War II Beagle Bay mission steadily increased its operations and influence in the Kimberley, developing a symbiotic relationship with the Aboriginal Affairs Department as it offered a practical and relatively cheap option for the care of Aboriginal and 'half-caste' or 'mixed race' children in the Kimberley. The Department, in turn, provided the mission with young people whom the missionaries hoped would become the foundation members of the Aboriginal Christian community in the Kimberley. By World War II the mission had established a community of Aborigines who were raised as Catholics, deeply entrenched in Catholic values and culture. The mission encouraged the young people whom they raised to marry other young Catholics within their community and to raise Catholic families. The missionaries' hope was that the Aboriginal Catholics, whom they cared for and carefully taught practical skills while providing them with a religious education, would eventually leave Beagle Bay Mission to evangelise their 'less civilised' brothers and sisters in communities throughout the Kimberley. In the process of this evangelisation, however, many of the Aboriginal people in the Kimberley who came under the influence of the Beagle Bay mission lost contact with their families and communities. Generations of others have been traumatised by loss of identity. Yet among many of the Aborigines who have been raised at Beagle Bay Mission there is an ambivalence in their attitude towards the missionaries and the Mission itself because for them it had become home.

\section{References}

'Bishop Gibney Diary', Sunday Times, 4 December 1927.

Choo, Christine, 1995, 'Asian Men on the West Kimberley Coast, 1900-1940' in Jan Gothard ed., Asian Orientations, Studies in Western Australian History, Vol. 16, 1995.

Choo, Christine, 1996, Aboriginal Women on Catholic Missions in the Kimberley, Western Australia, 1900-1950, PhD thesis, University of Western Australia.

Durack, Mary 1969, The Rock and the Sand, London.

Haebich, Anna 1988, For their Own Good: Aborigines and Government in the Southwest of Western Australia, 1900-1940, Nedlands.

McNair, William and Rumley, Hiliary 1981, Pioneer Aboriginal Mission: The Work of Wesleyan Missionary John Smithies in the Swan River Colony, 1840-1855, Nedlands.

49. McCarthy, G. Ah Mat \& B. Hancock, interviewed by the author, Darwin, 26 June 1992; V. Kanagae, interviewed by the author, Broome, 9 July 1992; R. Bin Amat, interviewed by the author, Broome, 10 July 1992.

50. Father E. Worms worked in the field of anthropology and linguistics. Father Kevin McKelson who was based in Broome and La Grange mission has been engaged in linguistics. 
Mechtilde, Sister 1961, The Missionary Adventures of the Sisters of St John of God, unpublished dissertation, award and institution unknown.

Nailon, Sister Brigida, c1987, 'Land of Wait and Wonder: Resource Notes on the Establishment of Roman Catholic Missions in the Kimberley', unpublished manuscript held in the archives of the Catholic Diocese of Broome and of the Pallottine Order.

Nailon, Sister Brigida and Father Francis Huegel (eds) 1990, This is Your Place: Beagle Bay Mission 1890-1990, Beagle Bay.

Stormon, E.J. 1977, The Salvado Memoirs, Nedlands.

Walter, Father George 1982, Australia: Land, People, Mission, Broome.

Zucker, Margaret 1994, From Patrons to Partners: A History of the Catholic Church in the Kimberley, 1884-1984, Fremantle. 